\title{
ANALISIS KEBUTUHAN POWER SUPLAI PADA ONLIMO OSS (OPEN SOURCE SOFTWARE) UNTUK PEMANTAUAN KUALITAS AIR SECARA REALTIME
}

\author{
Karina Anggraeni, Heru Dwi Wahjono, Irwan Kustianto \\ Pusat Teknologi Lingkungan, Badan Pengkajian dan Penerapan Teknologi \\ Gedung Geostech 820, Kawasan Puspiptek Serpong, Tangerang Selatan, Banten, 15314, Indonesia \\ Email: karina.anggraeni@bppt.go.id, irwan.kustianto@bppt.go.id, heru.dwi@bppt.go.id
}

\begin{abstract}
ABSTRAK
Riset dan pengembangan mengenai teknologi pemantauan kualitas air secara realtime terus dilakukan untuk dapat mengurangi produksi pembuatan data logger. Teknologi Onlimo OSS adalah sistem pemantuan kualitas air realtime yang menggunakan microprocessor sebagai data loggernya dan memanfaatkan aplikasi perangkat lunak terbuka yang berfungsi untuk mengendalikan kerja sensor dalam rangka pengambilan data kualitas air dan mengirimkannya ke pusat data. Pengembangan teknologi Onlimo OSS ini adalah sebuah teknologi pemantauan kualitas air secara online dan realtime yang memanfaatkan Raspberry Pi sebagai data logger dan menggunakan perangkat lunak terbuka. Penggunaan Raspberry Pi sebagai data logger lebih cepat diproduksi dibandingkan menggunakan microprocessor dan mudah menggantinya. Onlimo OSS ini menggunakan energi terbarukan berupa solar panel sehingga dapat diterapkan di remote area yang tidak dialiri pasokan listrik dari PLN. Analisa kebutuhan power supply untuk Onlimo OSS dengan langkah-langkah sebagai berikut : perhitungan total daya setiap peralatan yang digunakan pada Onlimo OSS, perhitungan total daya selama waktu tertentu sesuai kebutuhan Onlimo OSS, perhitungan kebutuhan solar panel, baterai dan solar charge controller serta pemilihan jenisnya, dan pembuatan rangkaian listrik untuk power supply Onlimo OSS. Power supply pada Onlimo OSS ini berjenis DC yang berasal dari baterai dan solar panel. Dengan ada penambahan baterai, Onlimo OSS ini memiliki fitur yang lebih banyak seperti webcam dan LED Matrix sehingga power supply ini sudah paling efisien.
\end{abstract}

Kata kunci: pemantauan kualitas air realtime, onlimo oss, data logger, Raspberry Pi, power supply, DC, solar panel, baterai, efisien

\section{ANALYSIS OF POWER SUPPLY REQUIREMENTS FOR ONLIMO OSS (OPEN SOURCE SOFTWARE) FOR REALTIME WATER QUALITY MONITORING}

\author{
Karina Anggraeni, Heru Dwi Wahjono, Irwan Kustianto \\ Center for Environmental Technology, Agency for Assessment and Application of Technology \\ Geostech Building 820, Puspiptek Area Serpong, South Tangerang, Banten, 15314, Indonesia \\ Email: karina.anggraeni@bppt.go.id, irwan.kustianto@bppt.go.id, heru.dwi@bppt.go.id
}

\begin{abstract}
Research and development on realtime water quality monitoring continues to be carried out to reduce the production of data loggers. Onlimo OSS technology is a realtime water quality monitoring system that uses a microprocessor as a data logger and utilizes open software applications that function to control the workings of sensors in order to collect water quality data and send it to data centers. Onlimo OSS technology development is an online and realtime water quality monitoring technology that utilizes Raspberry Pi as a data logger and uses open software. The use of Raspberry Pi as a data logger is produced faster than using a microprocessor and is easy to replace. Onlimo OSS uses renewable energy, namely solar panels so that it can be applied in remote areas that are not supplied by PLN. Analysis of power supply requirements for Onlimo OSS with the following steps: calculation of the total power of each equipment used on Onlimo OSS, calculation of total power for a certain time according to the needs of Onlimo OSS, calculation of solar panel requirements, battery and solar charge controller and type selection, and making electrical circuits for the Onlimo OSS power supply. The power supply on Onlimo OSS is a DC type that comes from batteries and solar panels. With the addition of batteries, Onlimo OSS has more features such as a webcam and LED Matrix so that this power supply is the most efficient.
\end{abstract}

Keywords: realtime water quality monitoring, onlimo oss, data logger, Raspberry Pi, power supply, $D C$, solar panels, batteries, efficient 


\section{PENDAHULUAN}

\subsection{Latar Belakang}

Pertumbuhan penduduk yang pesat di kota besar maupun di wilayah daerah aliran sungai, membawa dampak kepada pencemaran perairan sungai yang cukup besar. Sumber pencemar berasal dari buangan limbah domestik maupun limbah industri yang ada di daerah aliran tersebut. Selain itu pula peruntukan sungai dan fungsi sungai bergeser dari kondisi semula, ditandai dengan banyaknya bangunan ataupun tanggul-tanggul beton pada sepadan sungai (Wahjono et al, 2015).

Pemantuan kualitas air untuk mengendalikan pencemaran lingkungan telah dilakukan secara rutin oleh instansi pemerintah pusat maupun daerah. Kegiatan rutin pemantauannya dilakukan secara manual dengan mengambil sampling air pada beberapa periode waktu tertentu dan menganalisakannya ke laboratorium lingkungan (Suhendar et al, 2007). Pemantauan kualitas air yang telah dilakukan oleh instansi pemerintah sebagian besar hasilnya tidak dipublikasikan, sehingga tidak banyak masyarakat yang tahu mengenai kualitas air di wilayah sekitarnya. Pemantauan kualitas air secara manual yang telah dilakukan periodik banyak mengalami hambatan terutama masalah biaya yang besar dan waktu yang lama untuk melakukan pemantauan kualitas air (Wahjono, 2006).

Untuk mengatasi kendala tersebut, maka diperlukan riset dan pengembangan mengenai alat pemantauan kualitas air secara realtime. Dengan alat ini diharapkan dapat mengurangi biaya pengambilan sampel di setiap wilayah daerah aliran sungai. Selain itu juga mengurangi biaya analisa sampel, dimana hasil kualitas air dapat langsung dibaca dan diakses.

Teknologi Onlimo OSS adalah sistem pemantuan kualitas air realtime yang menggunakan microprocessor sebagai data loggernya dan memanfaatkan aplikasi perangkat lunak terbuka yang berfungsi untuk mengendalikan kerja sensor dalam rangka pengambilan data kualitas air dan mengirimkannya ke pusat data. Pengembangan teknologi Onlimo OSS ini adalah sebuah teknologi pemantauan kualitas air secara online dan realtime yang memanfaatkan Raspberry $\mathrm{Pi}$ sebagai data logger dan menggunakan perangkat lunak terbuka yaitu phyton. Selain banyak terdapat di pasaran harganya pun relatif murah, penggunaan Raspberry Pi sebagai data logger lebih cepat diproduksi dibandingkan menggunakan microprocessor dan mudah menggantinya. Untuk penggunaan microprocessor sendiri kurang visible jika digunakan untuk outdoor. Raspberry Pi dapat dengan mudah dirakit untuk menjadi sebuah data logger pemantuan kualitas air online dan realtime. Sumber arus listrik yang digunakan pada pengembangan Onlimo OSS ini adalah semuanya arus DC dimana berasal dari solar sel sehingga sudah tidak menggunakan inverter. Dengan pengembangan logger baru ini maka dibutuhkan analisa kebutuhan power supply agar logger dapat beroperasi dengan baik.

\subsection{Tujuan dan Sasaran}

Tujuan dari penelitian ini adalah untuk analisa kebutuhan power supply pada Onlimo OSS. Sasaran dari penelitian ini adalah terciptanya sistem power supply pada Onlimo OSS sesuai kebutuhan. Hasil penelitian ini diharapkan dapat menjadi bahan pertimbangan dalam pembuatan Onlimo OSS kedepannya untuk pemantauan kualitas air secara realtime.

\section{LINGKUP DAN METODOLOGI KEGIATAN}

Lingkup kegiatan rancang bangun kelistrikan pada Onlimo OSS untuk pemantauan kualitas air meliputi :

- Perhitungan total daya setiap peralatan yang digunakan pada Onlimo OSS

- Perhitungan total daya selama waktu tertentu sesuai kebutuhan Onlimo OSS

- Perhitungan kebutuhan solar panel, baterai dan solar charge controller serta pemilihan jenisnya

- Pembuatan rangkaian listrik untuk power supply Onlimo OSS

\section{HASIL DAN PEMBAHASAN}

\subsection{Peralatan pada Onlimo OSS}

a. Raspberry $\mathrm{Pi}$

Raspberry $\mathrm{Pi}$ ini digunakan sebagai otak untuk pemrograman dan pemrosesan pada Onlimo OSS. Raspberry $\mathrm{Pi}$, sering disingkat dengan nama Raspi, adalah komputer papan tunggal (single-board circuit; SBC) yang seukuran dengan kartu kredit yang dapat digunakan untuk menjalankan program perkantoran, permainan komputer, dan sebagai pemutar media hingga video beresolusi tinggi. Raspberry Pi dikembangkan 
oleh yayasan nirlaba, Rasberry Pi Foundation, yang digawangi sejumlah pengembang dan ahli komputer dari Universitas Cambridge, Inggris.

Raspberry Pi memiliki dua model: model A dan model B. Secara umum Raspberry $\mathrm{Pi}$ Model B memiliki kapasitas penyimpanan RAM sebesar 512 MB. Perbedaan model A dan $B$ terletak pada modul penyimpanan yang digunakan. Model A menggunakan penyimpanan sebesar $256 \mathrm{MB}$ dan penyimpanan model $B$ sebesar 512 MB. Selain itu, model B sudah dilengkapi dengan porta Ethernet (untuk LAN) yang tidak terdapat di model A. Desain Raspberry Pi didasarkan pada SoC (system-on-a-chip) Broadcom BCM2835, yang telah menanamkan prosesor ARM1176JZF-S dengan $700 \mathrm{MHz}$, GPU VideoCore IV, dan RAM sebesar $256 \mathrm{MB}$ (model B). Penyimpanan data tidak didesain untuk menggunakan cakram keras atau solidstate drive, melainkan mengandalkan kartu penyimpanan tipe SD untuk menjalankan sistem dan sebagai media penyimpanan jangka panjang.

Adapun terdapat 7 port pada circuit Raspberry, yaitu 4 port untuk USB, 1 port untuk ethernet, 1 port untuk HDMI, dan 1 port untuk audio.

Pada papan circuit, ditambahkan fan untuk mengeluarkan udara panas agar tidak terperangkap di rangkaian karena jika tidak disirkulasi dapat menyebabkan Raspberry cepat panas sehingga mengurangi lifetime. Power supply untuk Raspberry $\mathrm{Pi}$ ini sebesar 5 VDC, 2.1 Ampere(Wikipedia, 2019)).

Alasan pemilihan Raspberry $\mathrm{Pi}$ karena ukurannya yang kecil dan biaya rendah, dibandingkan dengan PC konvensional dan data logger, ditambah biaya nol perangkat lunak Linux (gratis). RPi 2 model $\mathrm{B}$, mikroprosesor berdaya rendah yang canggih dan mudah digunakan dengan elektronik onboard yang mendukung sejumlah besar perangkat input dan output, yang dianggap sebagai komputer terkecil di dunia.

$\mathrm{RPi}$ cocok untuk penggunaan pemula, dibandingkan dengan platform lain. $\mathrm{RPi}$ dibandingkan dengan sebagian besar sistem embedded berbasis Linux lainnya, seperti Arduino Yún, Beagle Bone Black dan Intel Galileo menunjukkan keuntungan seperti rasio biaya/manfaat yang lebih baik, komunitas pengguna yang lebih besar, bahasa pemrograman standar dan komunikasi, banyak pin input/output dan antarmuka grafis. Dianggap sebagai platform Do-It-Yourself (DiY) yang mudah bagi siswa yang tidak memiliki pengalaman dengan pengembangan perangkat lunak dan tertanam sistem, penggunaan RPi dimulai di sekolah dan universitas, tetapi sekarang semakin banyak diterapkan pada perusahaan, laboratorium penelitian dan proyek-proyek desainer independen. Bahasa seperti $\mathrm{C}, \mathrm{C}++$, Python atau Java dapat diakses secara online dengan materi yang disediakan oleh komunitas pengguna, berlawanan dengan perangkat lunak berpemilik yang biasanya tergantung pada bahasa pabrik(Renata et al, 2018)).

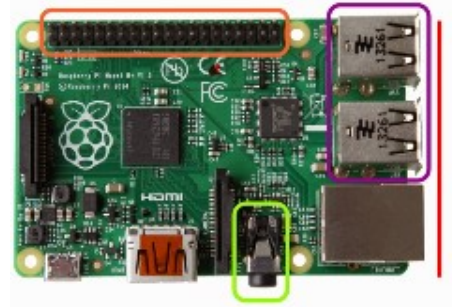

Raspberry Pi B+

Gambar 1. Raspberry Pi B+ (Wikipedia)

b. Multiprobe Sensor

Multiprobe sensor digunakan untuk mengukur beberapa parameter kualitas air sekaligus. Parameter kualitas air yang dapat diukur oleh sensor electrochemical yaitu (Hungarian Ministry for Environment and U.S., 1996)):

Tabel 1. Parameter electrochemical sensor

\begin{tabular}{|c|c|c|c|}
\hline No & Parameter & Satuan & Baku Mutu \\
\hline 1. & Dissolved Oxygen & $\mathrm{mg} / \mathrm{l}$ & $0-20$ \\
\hline 2. & Turbidity & $\mathrm{NTU}$ & $0-500$ \\
\hline 3. & Conductivity & $\mu \mathrm{S} / \mathrm{cm}$ & $0-2000$ \\
\hline 4. & Temperatur & ${ }^{\circ} \mathrm{C}$ & $0-50$ \\
\hline 5. & $\mathrm{pH}$ & - & $0-14$ \\
\hline 6. & Ammonium ion & $\mathrm{mg} / \mathrm{l}$ & $0-10$ \\
\hline 7. & TOC & $\mathrm{mg} / \mathrm{l}$ & $0-20$ \\
\hline 8. & Floating oil & - & - \\
\hline 9. & Chlorofyll-a & $\mu \mathrm{l} / \mathrm{l}$ & $0,1<$ \\
\hline 10. & Biomonitor & Index T & $0-15$ \\
\hline
\end{tabular}

Multiprobe sensor yang digunakan adalah produk dari DKK-TOA tipe WQC 24+ion. Spesifikasi teknis dari sensor tersebut adalah sebagai berikut :

- Kontruksi tahan air : $1 \mathrm{MPa}$

- Memori : Maksimal 3360 data

- Power Supply : 3 baterai AA

- Suhu Operasi : 0-50 ${ }^{\circ} \mathrm{C}$

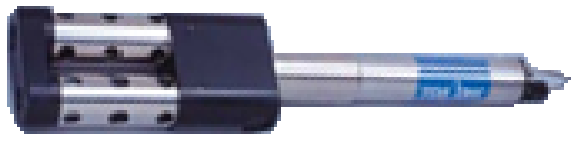


Gambar 2. Multiprobe Sensor(TOA DKK, 2015)

Multiprobe sensor DKK-TOA ini memiliki handheld. Spesifikasi dari handheld sebagai berikut :

- Display

: LCD Digital

- Kontruksi tahan air

: IP67 (JIS C 0920)

- Koneksi data

: RS 232C

- Analog output

: 0-1 VDC

- Open Collector Output : 36 VDC, 100 mA

- Power Source : 2 baterai AA atau adaptor

- Suhu Operasi $\quad: 0-50{ }^{\circ} \mathrm{C}$

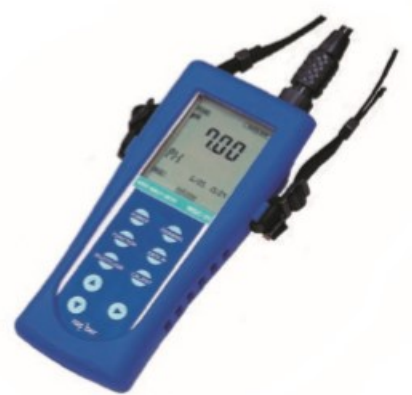

Gambar 3. Handheld Sensor DKK TOA(TOA DKK, 2015)

Koneksi antara handheld dengan multiprobe sensor DKK TOA menggunakan RS 232C (TOA DKK, 2015).

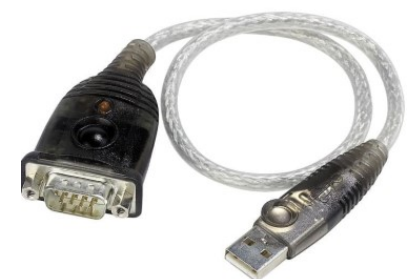

Gambar 4. Konektor Serial RS232C

c. LED Matrix

LED Matrix ini berfungsi untuk menampilkan hasil pengukuran kualitas air realtime dengan running text. Parameter yang ditampilkan diantaranya suhu DO, $\mathrm{pH}$, konduktivitas, TDS, salinitas, kekeruhan, SwSG, Ion Klor, Ion Nitrat, dan ORP. Power supply untuk LED Matrix ini sebesar 5 VDC, 1.5 Ampere.

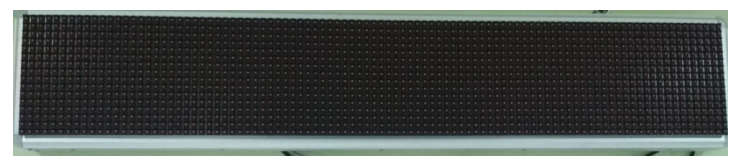

Gambar 5. LED Matrix

d. Webcam
Webcam digunakan untuk memantau dan merekam gambar secara langsung kondisi di sekitar Onlimo OSS saat kondisi pengukuran kualitas air. Webcam ini memiliki kapasitas 1280 × 720 pixels. Power supply untuk Webcam ini sebesar 5 VDC, 1 Ampere.

\subsection{Perhitungan Total Daya Selama Waktu Tertentu Sesuai Kebutuhan Onlimo OSS}

Total daya dapat dihitung dari jumlah daya masing-masing alat yang digunakan. Alat yang digunakan diantaranya Raspberry $\mathrm{Pi}$, Sensor kualitas air DKK TOA, LED Matrix dan webcam.

Tabel 2. Kebutuhan daya total

\begin{tabular}{|c|c|c|c|c|}
\hline No & Nama Alat & $\begin{array}{c}\text { Tegangan } \\
(\mathrm{V})\end{array}$ & $\begin{array}{c}\text { Arus } \\
\text { (Ampere) }\end{array}$ & $\begin{array}{c}\text { Daya } \\
(\text { Watt) }\end{array}$ \\
\hline 1 & Raspberry Pi & 5 & 2.1 & 10.5 \\
\hline 2 & $\begin{array}{c}\text { Sensor DKK } \\
\text { TOA }\end{array}$ & 7.5 & 11 & 7.5 \\
\hline 3 & LED Matrix & 5 & 5 & 25 \\
\hline 4 & Webcam & 5 & 1 & 5 \\
\hline \multicolumn{4}{|c|}{ Total Daya (Watt) } & 48 \\
\hline
\end{tabular}

Karena semua alat ini digunakan untuk pemantauan kualitas air secara realtime, maka alat ini akan bekerja selama 24 jam per hari. Total daya yang digunakan dalam 1 hari adalah sebesar $1221.12 \mathrm{~W}$ dengan memperhitungkan losses sebesar $6 \%$ seperti pada tabel berikut. Nilai $6 \%$ ini merupakan cadangan daya jika terjadi rugi-rugi daya.

Tabel 3. Total daya perhari dengan memperhitungkan losses

\begin{tabular}{|c|c|c|}
\hline $\begin{array}{c}\text { Lama alat } \\
\text { bekerja (jam) }\end{array}$ & Total Watt/hari & Losses 6\% \\
\hline 24 & 1152 & 1221.12 \\
\hline
\end{tabular}

\subsection{Perhitungan Kebutuhan Solar Panel, Baterai, Solar Charge Controller serta Pemilihan Jenisnya}

Onlimo OSS terbaru ini dapat ditempatkan di remote area yang tidak ada pasokan listriknya. Oleh karena itu untuk pasokan listriknya sendiri dirancang menggunakan panel surya. Selain angina, sel surya sebagai energi terbarukan cukup berpotensi diterapkan di Indonesia. Energi terbarukan dalam bentuk energi angin di Indonesia umumnya memiliki kecepatan rendah dengan nilai antara $3 \mathrm{~m} / \mathrm{s}$ 
dan $6 \mathrm{~m} / \mathrm{s}$. Total kapasitas terpasang energi angin saat ini adalah 1,9 MW, di mana $85 \%$ pembangkit energi angin berada di bagian timur Indonesia, dan sekitar $15 \%$ berada di bagian barat Indonesia. Tenaga surya juga diterapkan untuk menghasilkan listrik di Indonesia, walaupun intensitas radiasi matahari berfluktuasi sepanjang tahun dan berbeda dari satu tempat ke tempat lain. Total kapasitas terpasang tenaga surya untuk menghasilkan listrik adalah 13,5 MW. Ratarata, iradiasi matahari tinggi di bagian timur Indonesia, sedangkan iradiasi matahari menengah dan rendah ada di bagian barat Indonesia. Nilai terendah dari intensitas radiasi matahari adalah $4,2 \mathrm{kWh} / \mathrm{m}^{2}$ dan nilai tertinggi adalah $7,2 \mathrm{kWh} / \mathrm{m}^{2}$ (Erinofiardi et al, 2017). Penggunaan panel surya sebagai power supply data logger sudah diterapkan juga di luar negeri(Jiang et al, 2019)). Solar cell atau panel surya adalah alat untuk mengkonversi tenaga matahari menjadi energi listrik. Photovoltaic (PV) adalah teknologi yang berfungsi untuk mengubah atau mengkonversi radiasi matahari menjadi energi listrik secara langsung. PV biasanya dikemas dalam sebuah unit yang disebut modul. Dalam sebuah modul surya terdiri dari banyak sel surya yang bisa disusun secara seri maupun paralel. Sedangkan yang dimaksud dengan surya adalah sebuah elemen semikonduktor yang dapat mengkonversi energi surya menjadi energi listrik atas dasar efek fotovoltaik. Berikut adalah gambar dari solar cell(Kosasih, 2009).

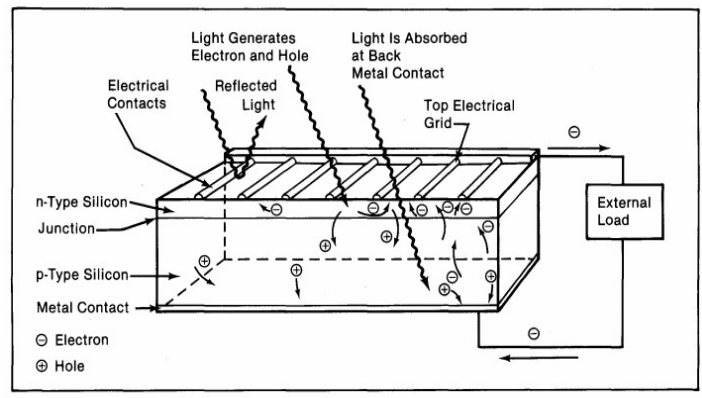

Gambar 6. Skema Sollar Cell(Hersch et al, 1982)

Fisik dari sel surya sangat mirip dengan bentuk klasik dioda p-n. Ketika cahaya diserap oleh junction, energi foton yang diserap di transfer ke sistem elektron dari dioda, menghasilkan penciptaan dari pembawa muatan mungkin saja sepasang elektron-ion dalam cairan elektrolit, atau sepasang electron-hole di dalam semikonduktor (Kosasih, 2009).
Asal dari tenaga potensial photovoltaic adalah perbedaan didalam kekuatan bahan kimia, disebut fermi level, dari elektronelektron di dua material yang terisolasi. Ketika mereka bergabung, Junction mendekati sebuah kesetimbangan termodinamik yang baru. Kesetimbangan tersebut didapat hanya ketika fermi level dalam kedua material sama. Hal ini muncul oleh aliran elektron dari satu material ke yang lain sampai sebuah perbedaan voltase terbentuk diantara dua material yang mana mempunyai potensial yang hanya sama dari awal perbedaan dari fermi level potensial ini mendorong photocurrent(Kosasih, 2009).

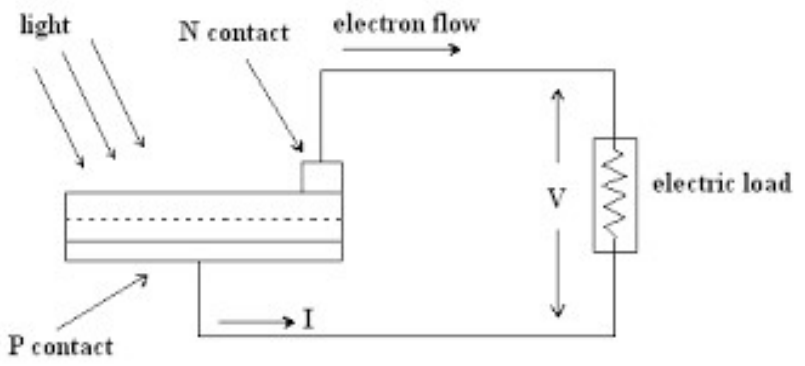

Gambar 7. Konversi foton ke voltase melalui P-N Junction (Kosasih, 2009)

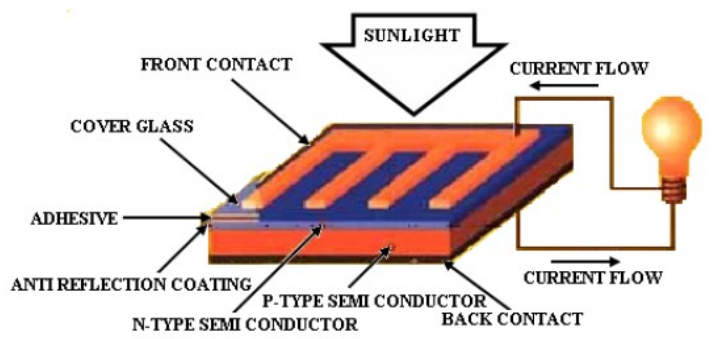

Gambar 8. Konstruksi dasar sel surya(Kosasih, 2009)

Gambar 8 menampilkan konstruksi dasar sel surya. Untuk mengumpulkan photocurrent, penghubung berbahan besi disediakan di kedua sisi dari junction untuk mengumpulkan arus listrik yang disebabkan oleh pergeseran foton dalam satu sisi. Foil penghantar (solder) disediakan di bawah permukaan dan satu di tepi atas permukaan.

Lubang penghantar tipis di atas permukaan mengumpulkan arus dan membiarkan sinar cahaya melaluinya. Ruang dari serat penghantar di dalam lubang adalah menimbulkan permasalahan antara memaksimalkan hantaran energi listrik dan meminimalisasi dari pemblokan sinar cahaya. Untuk mengatasi permasalahan dengan cara permukaan sel diberi pelapis anti-reflective 
untuk menyerap sebanyak mungkin cahaya dengan meminimalisasi pemantulan cahaya. Selain itu, dapat dilakukan perlindungan mekanik dengan coverglass yang dipasangkan dengan bahan yang transparan (Kosasih, 2009).

Penjelasan secara singkat bagaimana sel surya mengubah energi matahari menjadi energi listrik adalah sebagai berikut (Kosasih, 2009):

1) Foton di dalam cahaya matahari mengenai panel surya dan diserap oleh semiconducting material, seperti silikon.

2) Elektron (bermuatan negatif) dilepaskan dari atom, membiarkan mereka untuk mengalir melalui material panel surya untuk menghasilkan listrik. Muatan positif yang komplementer juga diciptakan (seperti gelembung) yang disebut holes dan mengalir dikembalikan arah elektron didalam suatu silikon panel surya.

3) Suatu array dari panel surya mengkonversi energi matahari ke dalam arus searah listrik (DC).

Sistem kelistrikan menggunakan pane surya setidaknya membutuhkan 2 komponen tambahan yaitu solar charge controller dan baterai (Jager et al, 2014). Listrik yang dihasilkan dari panel surya adalah listrik DC dengan tegangan $12 \mathrm{~V}$. Dari panel surya tegangan DC dialirkan menuju solar charge controller yang bertujuan agar tegangan listrik yang dihasilkan oleh panel surya tetap stabil untuk mengisi baterai(Erinofiardi et al, 2017)).

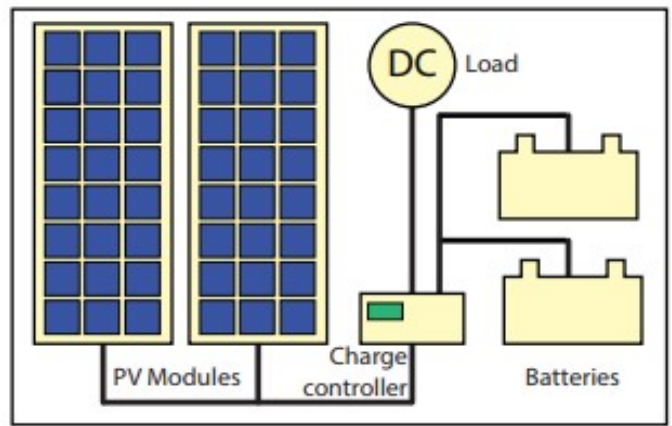

Gambar 9. Skema posisi solar charge controller dan baterai dalam sistem panel surya(Jager et al, 2014)

Kebutuhan solar panel dengan memperhitungkan 4 jam solar panel akan mencapai daya maksimum. Jam kerja efektif panel surya yaitu 3-5 jam/hari(Hakim et al, 2017). Jam kerja efektif ini sangat dipengaruhi oleh suhu dan cuaca(L. Premalatha \& Rahim, 2017). Solar panel yang dibutuhkan sebesar $350 \mathrm{~W}$. Dengan daya $350 \mathrm{~W}$ menggunakan 2 buah solar panel ukuran $150 \mathrm{Wp}$ dan 1 buah solar panel ukuran 50 Wp dipasang secara paralel.

Tabel 4. Kebutuhan Solar Panel

\begin{tabular}{|c|c|c|}
\hline $\begin{array}{c}\text { Kebutuhan } \\
\text { Watt total } \\
\text { solar panel }\end{array}$ & $\begin{array}{c}\text { Besar watt } \\
\text { solar panel } \\
\text { (4 jam peak) }\end{array}$ & $\begin{array}{c}\text { Kebutuhan } \\
\text { solar panel } \\
\text { (Watt) }\end{array}$ \\
\hline 1221.12 & 305.28 & 350 \\
\hline
\end{tabular}

Jenis solar panel yang dipilih adalah monokristal. Sel surya ini yang paling efisien dibandingkan jenis sel surya lainnya, sekitar $15 \%-20 \%$. Sel surya monokristal terbuat dari silikon yang berbentuk silinder. Untuk mengoptimalkan kinerja dan menurunkan biaya satu sel surya monokristalin, empat sisi dipotong yang memberi panel surya monokristalin tampilan yang khas. Ciri - ciri fisik dari jenis solar cell monokristal diantaranya bentuknya yang segidelapan, warna monokristal silicon juga lebih gelap(Bagher et al, 2015).

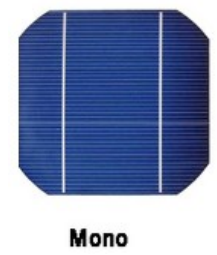

Gambar 10. Sel Monokristal(Bagher et al, 2015)

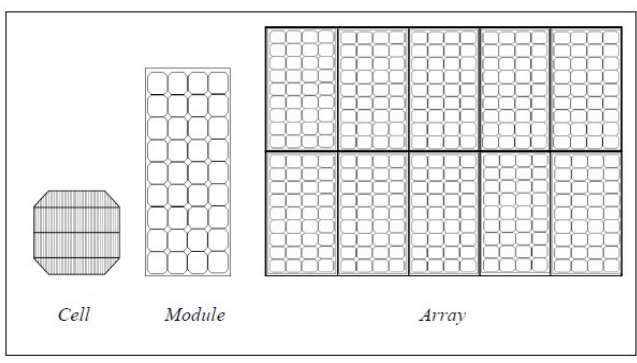

Gambar 11. Sel surya, modul dan array(Kosasih, 2009)

Setelah mendapatkan nilai total daya, dapat menghitung kebutuhan ampere baterai yang mempunyai efisiensi sebesar $50 \%$. Kebutuhan baterai sebesar 210,6 Ah.

Tabel 5. Kebutuhan Baterai

\begin{tabular}{|c|c|c|}
\hline Baterai (V) & $\begin{array}{c}\text { Kebutuhan } \\
\text { ampere baterai } \\
(\mathrm{A})\end{array}$ & $\begin{array}{c}50 \% \text { efisiensi } \\
(\mathrm{A})\end{array}$ \\
\hline
\end{tabular}


Jadi total baterai yang dibutuhkan adalah sebanyak 2 buah baterai dengan kapasitas 100 Ah. Baterai digunakan untuk menyimpan daya dari solar panel. Setelah dilakukan perhitungan, untuk memenuhi kebutuhan daya 1259.28 Watt, spesifikasi baterai yang digunakan adalah $12 \mathrm{~V}$ dan 100 Ah. Baterai yang dipakai di sistem ini adalah yang mempunyai tegangan $12 \mathrm{~V}$ berjenis deep cycle agar lebih tahan lama lifetime-nya. Agar efisiensi baterai tetap 50\% maka penggunaan sistem selama 24 jam hanya menghabiskan $50 \%$ dari baterai. Hal ini bertujuan untuk memperpanjang lifetime dari baterai.

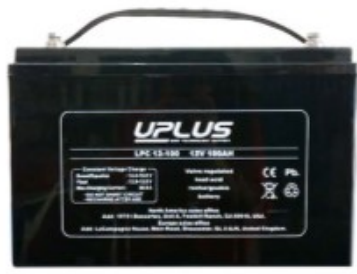

Gambar 12. Baterai

Perhitungan solar charge controller dengan membagi antara daya solar panel dan tegangan baterai $12 \mathrm{~V}$. Hasilnya, solar charge controller yang dibutuhkan mempunyai besaran arus sebesar minimum 30 Ah untuk menyesuaikan dengan daya keluaran dari solar panel. Pengontrol muatan surya (Solar Charger Controller) diperlukan di hampir semua sistem tenaga surya yang memanfaatkan baterai. Tugas pengontrol muatan surya adalah untuk mengatur daya yang keluar dari panel surya ke baterai(16). Mengisi daya baterai yang berlebihan setidaknya akan mengurangi masa pakai baterai dan resiko paling besar dapat merusak baterai hingga tidak dapat digunakan lagi. Ada 2 jenis solar charger controller yaitu Pulse Width Modulation (PWM) dan Maximum Power Point Tracker (MPPT).

Tabel 6. Perbedaan antara PWM dan MPPT(C.A. \& Edeko, 2015)

\begin{tabular}{|c|c|}
\hline PWM & MPPT \\
\hline $\begin{array}{ll}\text { PV array } & \text { dan } \\
\text { tegangan } & \text { baterai } \\
\text { harus sama. } & \end{array}$ & $\begin{array}{l}\text { Tegangan PV array } \\
\text { dapat lebih tinggi } \\
\text { dibandingkan } \\
\text { tegangan baterai. }\end{array}$ \\
\hline $\begin{array}{l}\begin{array}{l}\text { Beroperasi pada } \\
\text { tegangan baterai } \\
\text { sehingga ideal jika } \\
\text { temperatur cukup }\end{array}\end{array}$ & $\begin{array}{l}\text { Dapat beroperasi di } \\
\text { atas tegangan } \\
\text { baterai sehingga } \\
\text { dapat mendorong }\end{array}$ \\
\hline
\end{tabular}

\begin{tabular}{|c|c|}
\hline $\begin{array}{l}\text { hangat dan kapasitas } \\
\text { baterai } 80 \% \text {. }\end{array}$ & $\begin{array}{l}\text { pengisian lebih } \\
\text { cepat pada kondisi } \\
\text { temperatur dingin } \\
\text { dan kapasitas } \\
\text { baterai rendah. }\end{array}$ \\
\hline $\begin{array}{l}\text { Kontrol PWM } \\
\text { dibangun } \\
\text { berdasarkan } \\
\text { teknologi yang teruji } \\
\text { waktu yaitu telah } \\
\text { digunakan selama } \\
\text { bertahun-tahun } \\
\text { dalam sistem solar. }\end{array}$ & $\begin{array}{l}\text { Kontroler MPPT } \\
\text { menawarkan potensi } \\
\text { peningkatan } \\
\text { efisiensi pengisian } \\
\text { hingga } 30 \% \text {. }\end{array}$ \\
\hline $\begin{array}{l}\text { Kontroler PWM pada } \\
\text { umumnya berharga } \\
\text { murah. }\end{array}$ & $\begin{array}{lr}\text { Kontroler } & \text { MPPT } \\
\text { berharga } & \text { lebih } \\
\text { mahal dibandingkan } \\
\text { PWM. }\end{array}$ \\
\hline 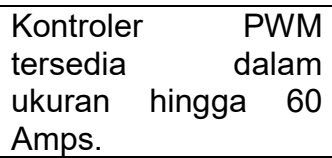 & $\begin{array}{l}\text { Kontroler MPPT } \\
\text { tersedia dalam } \\
\text { ukuran hingga } 80 \\
\text { Amps. }\end{array}$ \\
\hline $\begin{array}{l}\text { Biasa digunakan } \\
\text { pada kapasitas } \\
\text { sistem kecil. }\end{array}$ & $\begin{array}{l}\text { Kapasitas sistem } \\
\text { besar atau di atas } \\
200 \text { W lebih ideal } \\
\text { menggunakan SCC } \\
\text { MPPT. }\end{array}$ \\
\hline $\begin{array}{l}\text { Susunan panel surya } \\
\text { dihitung pada } \\
\text { ampere } \\
\text { (berdasarkan arus } \\
\text { yang dihasilkan saat } \\
\text { solar panel bekerja } \\
\text { sesuai } \quad \text { dengan } \\
\text { tegangan baterai). }\end{array}$ & $\begin{array}{l}\text { Susunan panel } \\
\text { surya dihitung } \\
\text { berdasarkan watt } \\
\text { (maksimum } \\
\text { charging current x } \\
\text { battery voltage). }\end{array}$ \\
\hline $\begin{array}{lr}\text { Tegangan } & \text { kerja } \\
\text { hanya } & \text { mampu } \\
\text { menyesuaikan } & \\
\text { tegangan baterai. } \\
\text { Jika tegangan yang } \\
\text { dihasilkan r solar } \\
\text { panel di bawah } \\
\text { tegangan r kerja } \\
\text { baterai, r secara } \\
\text { otomatis sistem solar } \\
\text { panel ridak } \\
\text { melakukan pengisian } \\
\text { ke baterai. }\end{array}$ & 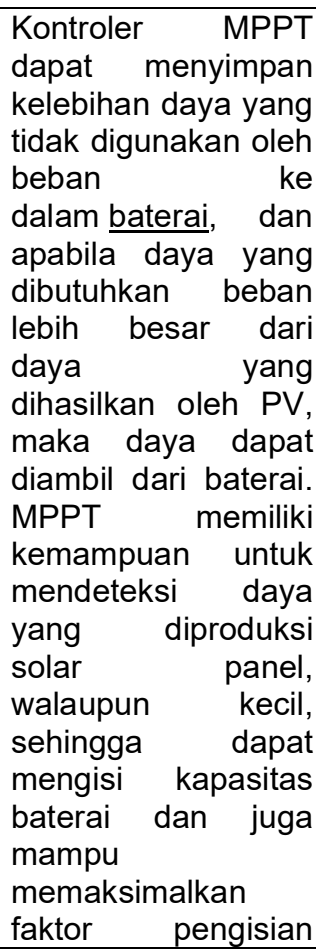 \\
\hline
\end{tabular}




\begin{tabular}{|l|l|}
\hline & $\begin{array}{l}\text { kapasitas secara } \\
\text { lebih besar. }\end{array}$ \\
\hline $\begin{array}{l}\text { Kontroler PWM } \\
\text { tahan lama, } \\
\text { sebagian besar } \\
\text { dengan pendingin } \\
\text { gaya pendingin pasif. }\end{array}$ & $\begin{array}{l}\text { Lifetime kontroler } \\
\text { MPPT biasanya } \\
\text { lebih panjang dari } \\
\text { unit PWM. }\end{array}$ \\
\hline $\begin{array}{l}\text { Pengontrol ini } \\
\text { tersedia dalam } \\
\text { berbagai ukuran } \\
\text { untuk } \\
\text { aplikasi. berbagai }\end{array}$ & $\begin{array}{l}\text { Kontroler MPPT } \\
\text { menawarkan } \\
\text { fleksibilitas besar } \\
\text { untuk berbagai } \\
\text { sistem, satu-satunya } \\
\text { cara untuk mengatur } \\
\text { modul koneksi grid } \\
\text { untuk mengisi daya } \\
\text { baterai. }\end{array}$ \\
\hline $\begin{array}{l}\text { Kontroler PWM } \\
\text { ukuran fisik kecil }\end{array}$ & $\begin{array}{l}\text { Kontroler MPPT } \\
\text { umumnya lebih } \\
\text { besar dalam ukuran } \\
\text { fisik dibandingkan } \\
\text { PWM. }\end{array}$ \\
\hline
\end{tabular}

Solar charge controller yang digunakan untuk Onlimo OSS ini adalah yang berjenis MPPT yang mempunyai efisiensi sebesar $80 \%$.

\subsection{Pembuatan Rangkaian Listrik Untuk Power Supply Onlimo OSS}

Fitur yg terdapat di Onlimo OSS terbaru ini adalah adanya tampilan dari sensor DKK TOA melalui LCD dan tampilan di running text (LED Matrix). Selain itu juga ditambahkan webcam yang bertujuan memantau dan merekam gambar secara langsung kondisi di sekitar Onlimo OSS saat kondisi pengukuran kualitas air. Output dari baterai adalah sebesar $12 \mathrm{~V}$ sedangkan input untuk Raspberry $\mathrm{Pi}$, sensor DKK TOA, webcam, dan LED Matrix membutuhkan tegangan $5 \mathrm{~V}$ maka ditambahkan regulator $5 \mathrm{~V}$ pada output baterai. Fitur-fitur ini akan tersambung dengan Raspberry $\mathrm{Pi}$ menggunakan port USB menggunakan komunikasi serial. Sedangkan LCD yang akan menampilkan hasil pengukuran dari sensor kualitas air tersambung ke port HDMI dari Raspberry Pi.

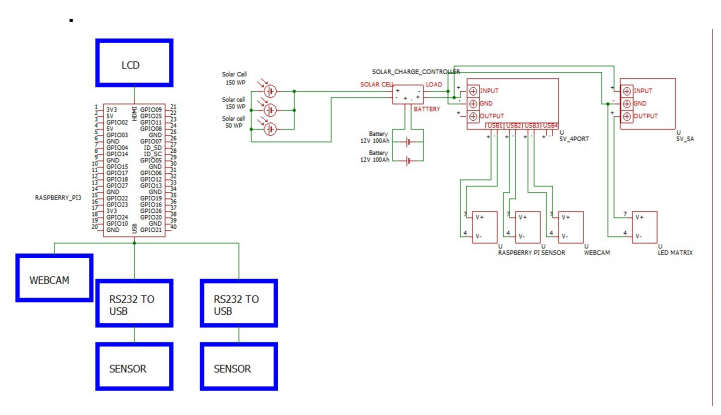

\section{Gambar 13. Diagram rangkaian elektrik} ONLIMO OSS

Raspberry $\mathrm{Pi}$, sensor DKK TOA, dan webcam membutuhkan tegangan $5 \mathrm{~V}$ low current sedangkan untuk LED Matrix membutuhkan tegangan 5V high current yaitu membutuhkan arus sebanyak $5 \mathrm{~A}$. Oleh karena itu, dibutuhkan regulator penurun tegangan khusus untuk power supply LED Matrix. Regulator yang dibutuhkan harus mempunyai output arus sebesar $5 \mathrm{~A}$ sehingga dipilih yang bertipe buck converter

Regulator yang digunakan Raspberry $\mathrm{Pi}$, sensor DKK TOA, dan webcam spesifikasinya menggunakan chip tps40057 yang mempunyai output sebanyak 4 slot USB. Besaran arusnya adalah $5 \mathrm{~A}$ yang dibagi 4 di masing-masing slot output, sedangkan tegangan sebesar $5 \mathrm{~V}$ di masing-masing slot USB.

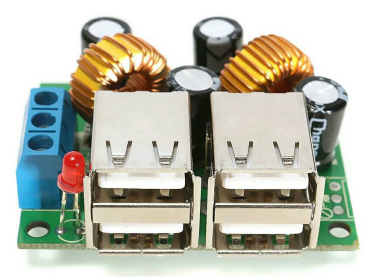

Gambar 14. Regulator 5V 4 USB Output(store qkits, 2019)

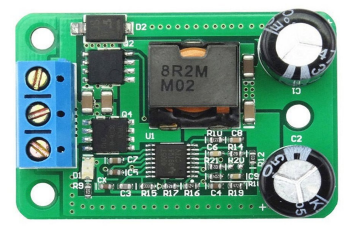

Gambar 15. Regulator 5V High Current 5A(Store qkits, 2019)

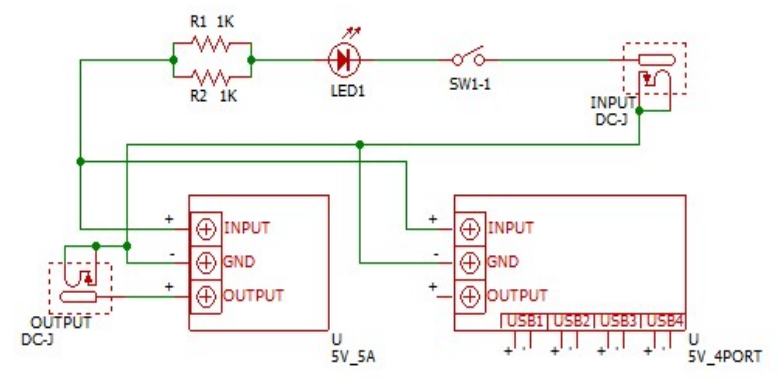

Gambar 16. Diagram rangkaian power supply

Regulator kedua untuk LED Matrix mempunyai spesifikasi high current yaitu pada outputnya menghasilkan arus sebesar 5A. 
Regulator ini khusus untuk power supply LED Matrix dimana membutuhkan tegangan dengan arus listrik yang besar.

Kedua regulator ini akan dirangkai secara paralel di dalam satu kotak power supply yang akan menggunakan saklar untuk mengaktifkannya. Regulator ini akan mendapatkan sumber tegangan yang berasal dari solar charge controller.

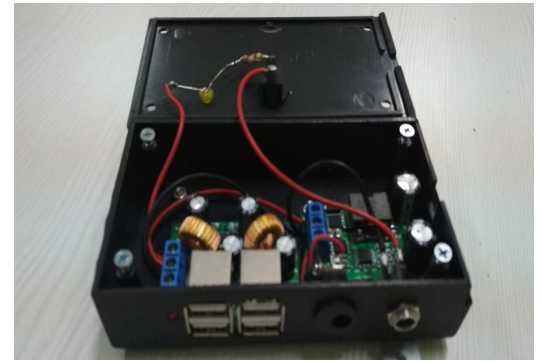

Gambar 17. Power Supply Onlimo OSS

Berikut perakitan kabel dan peralatan pada logger sesuai pada Gambar 18.

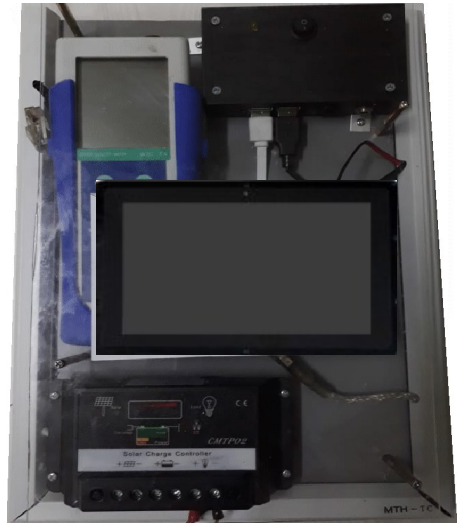

Gambar 18. Perakitan kabel dan peralatan

Onlimo OSS ini diinstal di atas IPAL Gedung Geostech 820 BPPT, Puspiptek Serpong.

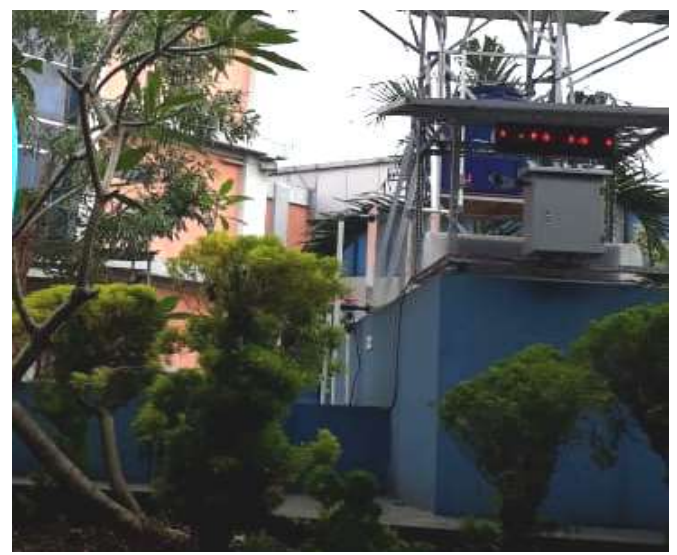

Gambar 19. Onlimo OSS yang sudah terinstal

Perbedaan Onlimo OSS versi lama dan versi baru adalah sebagai berikut :

Tabel 7. Perbedaan Onlimo OSS lama dan baru

\begin{tabular}{|c|c|c|c|}
\hline No & Parameter & $\begin{array}{l}\text { Onlimo OSS } \\
\text { versi lama }\end{array}$ & $\begin{array}{c}\text { Onlimo } \\
\text { OSS versi } \\
\text { baru }\end{array}$ \\
\hline 1 & Processor & Microprocessor & $\begin{array}{l}\text { Raspberry } \\
\mathrm{Pi}\end{array}$ \\
\hline 2 & $\begin{array}{l}\text { Bahasa } \\
\text { Pemrograman }\end{array}$ & $\mathrm{C}++$ & Phyton \\
\hline 3 & Input daya & $A C$ dan $D C$ & $\mathrm{DC}$ \\
\hline 4 & $\begin{array}{l}\text { Kebutuhan } \\
\text { power supply }\end{array}$ & $\begin{array}{l}\text { - } \text { Microprocess } \\
\text { or } 220 \text { VAC } \\
\text { - Sensor } \\
\text { multiprobe } 12 \\
\text { VDC }\end{array}$ & $\begin{array}{ll}\text { - } & \text { Raspberr } \\
\text { y Pi } 5 \\
\text { VDC, } 2.1 \\
\text { A } \\
\text { - Sensor } \\
\text { multiprob } \\
\text { e } 6 \text { VDC, } \\
1.5 \mathrm{~A} \\
\text { - LED } \\
\text { Matrix, } 5 \\
\text { VDC, 5A } \\
\text { - Webcam } \\
\text { 5VDC, } \\
\text { 1A }\end{array}$ \\
\hline 5 & $\begin{array}{l}\text { Media } \\
\text { penyimpan }\end{array}$ & $\begin{array}{l}\text { 16GB USB } \\
\text { Highspeed } \\
\text { Flash Disk } \\
\text { (>30 MB/S) }\end{array}$ & - $\begin{array}{l}\text { Micro SD } \\
32 \mathrm{~GB}\end{array}$ \\
\hline 6 & $\begin{array}{l}\text { Media } \\
\text { Komunikasi }\end{array}$ & $\begin{array}{l}\text { USB Wifi } \\
\text { Adaptor (TP } \\
\text { Link W321G) }\end{array}$ & - $\begin{array}{l}\text { Wifi/GS } \\
M\end{array}$ \\
\hline
\end{tabular}

Onlimo OSS baru ini sudah mengguanakan energi terbarukan berupa solar panel sehingga dapat diterapkan di remote area yang tidak ada pasokan listrik. Sedangkan untuk Onlimo OSS versi lama belum menggunakan solar panel sehingga sangat bergantung dengan adanya pasokan listrik dari PLN. Untuk power supply dari Onlimo OSS baru juga sudah DC semua, sedangkan untuk yang versi lama masih menggunakan $\mathrm{AC}$ dan DC.

\section{KESIMPULAN}

Kegiatan pengembangan Onlimo OSS ini untuk menyediakan alternatif teknologi pemantauan kualitas air menggunakan komponen yang ada di pasaran dan penggunaan bahasa pemrogaman terbuka yaitu Phyton. Beberapa kesimpulan yang 
dapat ditarik dari kegiatan ini adalah sebagai berikut :

- Pengembangan sistem pemantuan kualitas air Onlimo OSS dengan memanfaatkan solar panel agar dapat diimplementasikan pada daerah yang tidak memiliki pasokan listrik dari PLN.

- Raspberry Pi dapat digunakan sebagai otak pemrosesan dan pemrograman Onlimo OSS untuk pemantuan kualitas air.

- Onlimo OSS ini dilengkapi dengan fitur tampilan dengan LCD, running text dengan LED Matrix dan webcam.

- Kebutuhan power supply pada Onlimo OSS ini DC yang berasal dari baterai dan solar panel.

- Secara umum uji coba Onlimo OSS di outdoor test memberikan hasil, bahwa sistem dapat bekerja secara terus menerus selama kurang lebih 10 bulan.

\section{DAFTAR PUSTAKA}

1. Wahjono, Heru Dwi dkk. 2015. Buku Sistem Pemantauan Online Untuk Pengendalian Pencemaran Kualitas Air Sungai di DAS Ciliwung. Pusat Teknologi Lingkungan - BPPT.

2. Suhendar I. Sachoemar dan Heru Dwi Wahjono. 2007. Kondisi Pencemaran Lingkungan Perairan di Teluk Jakarta. JAI Vol 3 No. 1. 2007. PTL BPPT.

3. Wahjono, Heru Dwi. 2006. Sistem Pemantauan Online (ONLIMO) Kualitas Air dengan Menggunakan Sistem Komunikasi GSM. Jurnal Teknologi Lingkungan Vol. 7 No. 2 Hal. 115-128.

4. Wikipedia.2019.(https://id.wikipedia.org/wiki /Raspberry_Pi)

5. Renata I.S. Pereira, dkk. 2018. IoT embedded linux system based on Raspberry $\mathrm{Pi}$ applied to real-time cloud monitoring of a decentralized photovoltaic plant. Laboratory of Alternative Energies, Electrical Eng. Department, PICl Campus, Federal University of Ceará, 60455-760 Fortaleza, Brazil. LAESE Laboratory, Telematics, Federal Institute of Ceará, Industrial District I, 61939-140 Maracanaú, Brazil. Measurement Volume 114, January 2018, Pages 286-297.

6. Hungarian Ministry for Environment and U. S. Agency for International Development.
1996. Basic instrumentation of monitoring station (http://www.rivermonitoring.hu).

7. DKK TOA. 2015. Brochure Water Quality Meter Model WQC-24. DKK-TOA Corporation.

8. Erinofiardi, dkk. 2017. A review on micro hydropower in Indonesia. 1st International Conference on Energy and Power, ICEP2016, 14-16 December 2016, RMIT University, Melbourne, Australia. Energy Procedia 110(2017) 316 - 321

9. Jiang, Bojian dan M. Tariq Iqbal. 2019. Open Source Data Logging and Data Visualization for an Isolated PV System. Faculty of Engineering and Applied Science. Memorial University of Newfoundland (MUN). St. John's, NL A1B 3X5, Canada.

10. Hersch, Paul dkk. 1982. Basic Photovoltaic Principles and Methods. Solar Energy Research Institute. U.S. Department of Energy.

11. Klaus Jäger, dkk. 2014. Book of Solar Energy Fundamentals, Technology, and Systems. Delft University of Technology.

12. Kosasih, Agus. 2009. Rancang Bangun Sistem Penjejak Matahari untuk Mengoptimalkan Tegangan Sel Surya. Teknik Elektro. Universitas Komputer Indonesia.

13. Hakim, Fahmi Muhammad. 2017. Perancangan Rooftop Off Grid Solar Panel Pada Rumah Tinggal Sebagai Alternatif Sumber Energi Listrik, Polinema, Malang.

14. L, Premalatha and Rahim N.A. 2017. The Effect of Dynamic Weather Conditions on Three Types of PV Cell Technologies - A Comparative Analysis. 1st International Conference on Power Engineering, Computing and Control, PECCON-2017, 24 March 2017, VIT University, Chennai Campus.

15. Bagher, Askari Mohamma, Vahid, Mirzaei Mahmoud Abadi, Mohsen, Mirhabibi. 2015. American Journal of Optics and Photonics: Types of Solar Cells and Application. Payame Noor University, Tehran, Iran, Shahid Bahonar University, Kerman, Iran.

16.C.A. Osaretin and Edeko F.O. 2015. Design and Implementation of a Solar Charge Controller with Variable Output. Journal of Electrical and Electronic 
Engineering Vol.12 No. 2 ISSN 1118 5058
17.Regulator $5 \mathrm{~V} \quad 4 \quad$ USB $\quad$ Output (https://store.qkits.com/dc-12v-step-down5v-5a-4-usb-ports.html).

18. Regulator 5V High Current 5A. (https://guide.alibaba.com/shop/qianson$25 \mathrm{w}$-dc-dc-buck-converter-9v-35v-12v$24 \mathrm{v}$-to-5v-5a-step-down-voltage-regulatorpower-supply-module_1007734258.html). 